\title{
Revisiting the One-Step Synthesis of Heteroleptic Lanthanide(III) (Porphyrinato)(Phthalocyaninates): Opportunities and Limitations
}

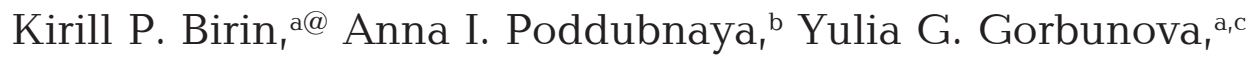 \\ and Aslan Yu. Tsivadze ${ }^{\mathrm{a}, \mathrm{c}}$ \\ ${ }^{a}$ A.N. Frumkin Institute of Physical Chemistry and Electrochemistry RAS, 119071 Moscow, Russia \\ ${ }^{\mathrm{b}}$ D.I. Mendeleev University of Chemical Technology of Russia, 125047 Moscow, Russia \\ ${ }^{\mathrm{N}}$ N.S. Kurnakov Institute of General and Inorganic Chemistry RAS, 119991 Moscow, Russia \\ ${ }^{@}$ Corresponding authorE-mail:kirill.birin@gmail.com
}

\begin{abstract}
The influence of the porphyrin and phthalocyanine ligand nature onto the yield and selectivity in the one-step synthesis of heteroleptic triple-decker early lanthanide (porphyrinato)(phthalocyaninates) is investigated with 6 porphyrins, 4 phthalocyanines and 2 lanthanides as examples. It is found that the presence of electron-donating substituents in the phthalocyanine macrocycle allows efficient one-step formation of symmetrical triple-decker complexes of [Por]Ln[Pc]Ln[Por] type. In contrast, in the case of unsubstituted phthalocyanine only formation of double-decker complex was observed. The method was found to be limited for the preparation of complexes, containing porphyrins with unsubstituted meso-positions because of their degradation upon reaction course as well as porphyrins with bulky meso-substituents as a result of steric hindrances.
\end{abstract}

Keywords: Lanthanides, porphyrins, phthalocyanines, heteropleptic sandwich complexes.

\section{ОАностадийный синтез гетеролептических (порфиринато) (фтахоцианинатов) лантанидов: границы применимости}

\author{
К. П. Бирин, ${ }^{a} @$ А. И. Поддубная, ${ }_{1}^{\mathrm{b}}$ Ю. Г. Горбунова, ${ }^{\mathrm{a}, \mathrm{c}}$ А. Ю. Цивадзз $\mathrm{e}^{\mathrm{a}, \mathrm{c}}$ \\ ${ }^{a}$ анститут физической химии и электрохимии им. А.Н. Фрумкина РАН, 119071 Москва, Россия \\ ${ }^{\mathrm{b}}$ Российский химико-технологический университет им. Д.И. Менделеева, 125047 Москва, Россия \\ ${ }^{\mathrm{c}}$ Институт общей и неорганической химии им. Н.С. Курнакова РАН, 119991 Москва, Россия \\ @E-mail: kirill.birin@gmail.com
}

\begin{abstract}
В работе изучено влияние природы порфириновых и фталоцианиновых лигандов на выход и селективность одностадийного метода синтеза гетеролептических (порфиринато)(фталочуианинатов) лантанидов начала ряда на примере 6 порфиринов, 4 фталочианинов и 2 ионов лантанидов. Показано, что присутствие электронодонорных заместителей в периферийных положениях фталоцианинового лиганда определяет возможность селективного образования трехпалубных комплексов строения [Por]Ln[Pc]Ln[Por]. Hanротив, в случае незамещенного фталочианина наблюдается образование исключительно гетеролептического двухпалубного комплекса. Обнаружено, что в изученных условиях невозможно получение комплексов, содержаших 5,15-диарилпорфирин, в силу его нестабильности в условиях реакции. Кроме того, увеличение стерических характеристик заместителей в мезо-положениях препятствует образованию сэндвичевых гетеролептических комплексов.
\end{abstract}

Ключевые слова: Лантаниды, порфирины, фталоцианины, гетеролептические сэндвичевые комплексы. 


\section{Introduction}

Heteroleptic sandwich-type complexes containing tetrapyrrolic ligands are promising starting compounds for the development of novel materials with unique properties. ${ }^{[1]}$ The electron-reach conjugated $\pi$-system of lanthanide heteroleptic (porphyrinato)(phthalocyaninates) determines large set of their electrochemical redox-transitions. ${ }^{[2,3]}$ The unique electrochemical properties of these compounds enabled their investigations from the point of molecular information storage applications. ${ }^{[4]}$ Lindsey et al. have found that the largest set of redox transitions within narrow range of potentials can be attained in the case of heteroleptic triple-decker (porphyrinato)(phthalocyaninates) containing different lanthanide metal centers and different substituents in the macrocyclic decks. ${ }^{[5,6]}$ Complexes with various functional tetrapyrrolic ligands have revealed single molecule magnet properties. ${ }^{[1,7-11]}$ Non-linear optics, ${ }^{[12]}$ and two-photon absorption ${ }^{[13]}$ have also been shown to be the strengths of heteroleptic lanthanide (porphyrinato)(phthalocyaninates).

Hence, the targeted synthesis of heteroleptic sandwichtype complexes with desired arrangement of tetrapyrrolic ligands remains an actual task. ${ }^{[14]}$ The typical approach consists in stepwise construction of the target molecule starting from the formation of lanthanide mono-porphyrinate or phthalocyaninate, with subsequent introduction of the following ligand or its precursor. ${ }^{[11,15-17]}$ Another case is the interaction between in situ generated lanthanide mono-porphyrinate and a pre-synthesized double-decker complexes. ${ }^{[17-19]}$ Altogether these approaches allow preparation of various heteroleptic lanthanide complexes containing equal or different metal centers for electrochemical or magnetic application.

On the other hand, the stepwise synthetic strategy possesses several considerable drawbacks. First of all, the decrease of overall yields of the final products are observed. Moreover, the experimental implementations of this strategy turn out to be excessively complicated. In this respect, the statistical syntheses of lanthanide heteroleptic complexes have attained notable interest. The enhanced selectivity in this type of synthesis of heteroleptic tripledecker complexes was found to be dependent on the electronic properties of the phthalocyanine ligand. ${ }^{[20,21]}$

The mentioned peculiarities have forced us to investigation of simplified but yet efficient approaches towards heteroleptic lanthanide (porphyrinato)(phthalocyaninates). Previously we have developed an efficient one-step procedure for the selective preparation of the heteroleptic lanthanide tripledecker complexes of [Por]Ln[Pc]Ln[Por] structure ${ }^{[19,21-25]}$ and briefly demonstrated their promising optical and redox properties $^{[22]}$ as well as their potential application as colorimetric sensors. ${ }^{[25,26]}$ The selective formation of the complexes with central phthalocyanine deck was observed, and the selectivity was explained by the unsymmetrical distribution of the electron density in the double-decker semiproducts. In present work we report the scope and limitations of this approach for the preparation of the complexes with various porphyrinato- and phthalocyaninato-ligands.

\section{Experimental}

1-Hexanol (HexOH, Acros Organics, $98 \%$ ) was used freshly distilled over Na. Chloroform was used freshly distilled over $\mathrm{CaH}_{2}$.
$\mathrm{MeOH}$ (99\%, Merk), $\mathrm{CDCl}_{3}$ (99.8\%, Aldrich) and hexane (analytical grade) were used as obtained without further purification. Acetylacetonates of $\mathrm{La}, \mathrm{Nd}$ and $\mathrm{Eu}$ ( $99 \%$, Aldrich), 4-bromobenzaldehyde (99\%, Aldrich), hydrazine monohydrate (100\%, Acros Organics) and propionic acid (Riedel de Haën, $99 \%$ ) were also used as obtained. Pyrrole (99\%, Acros Organics) and 1,8-diazabicyclo[5.4.0]undec-7-en (DBU, Merck, $>97 \%$ ) were used freshly distilled over $\mathrm{CaH}_{2}$. Free-base tetraarylporphyrins, ${ }^{[27]}$ 4,5-dibutoxyphthalonitrile ${ }^{[28]}$ and 4,5-dicyanobenzo-(15-crown-5) (DCB$15 \mathrm{C} 5)^{[28,29]}$ were prepared according to published conventional procedures.

Chromatographic separation and purification of complexes was performed at cylindrical glass columns filled with neutral alumina (Merck, $0.063-0.2 \mathrm{~mm}$ ) or silica gel (Macherey-Nagel, Silica $60,0.063-0.2 \mathrm{~mm}$ ).

UV-Vis absorption spectra were recorded in $250-900 \mathrm{~nm}$ spectral range with Unicam UV-Vis spectrophotometer UV4 in $10 \mathrm{~mm}$ rectangular quartz cells. MALDI-TOF mass spectra were obtained on Bruker Daltonics Ultraflex mass-spectrometer in positive ion mode with nicotinic acid as a matrix.

NMR spectra were recorded at Bruker Avance-III spectrometer with $600.31 \mathrm{MHz}$ frequency at $303 \mathrm{~K}$. Samples with concentration $c a \cdot 10^{-4}-10^{-6} \mathrm{M}$ were prepared in $\mathrm{CDCl}_{3}$. Chemical shifts were measured relatively to residual solvent signals $\left(\mathrm{CHCl}_{3}\right.$, $\delta=7.24 \mathrm{ppm})$.

General procedure for preparation of heteroleptic complexes. The mixture of $\operatorname{Ln}(\mathrm{acac})_{3}(0.4 \mathrm{mmol})$, free-base porphyrin $(0.1 \mathrm{mmol})$, phthalonitrile $(0.4 \mathrm{mmol})$, and DBU $(100 \mu \mathrm{l}$, $0.66 \mathrm{mmol})$ was refluxed in 1-hexanol $(8 \mathrm{ml})$ for $24 \mathrm{~h}$ under slow stream of dry argon. The reaction mixture was cooled to room temperature and added dropwise into $50 \mathrm{ml}$ of hexane. The dark precipitate was filtered and washed with hexane. Chloroform solution of the residue was applied on chromatographic column filled with neutral alumina. The column was eluted with $\mathrm{CHCl}_{3}-\mathrm{MeOH}$ mixture $(0-5 \% \mathrm{v} / \mathrm{v} \mathrm{MeOH})$. Greenish-brown fraction of symmetrical triple-decker complex [Por] $\operatorname{Ln}[\mathrm{Pc}] \mathrm{Ln}[\mathrm{Por}]$ typically was collected at $0.5-1 \%$ of $\mathrm{MeOH}$ in eluent. The isolated triple-decker complexes were repeatedly purified from traces of starting phthalonitrile at silica gel with $\mathrm{CHCl}_{3}-\mathrm{MeOH}$ mixture $(0-1 \% \mathrm{v} / \mathrm{v} \mathrm{MeOH})$.

$\mathrm{Nd}_{2}\left[\mathrm{Br}_{4} \mathrm{TPP}\right]_{2}\left[(\mathrm{BuO})_{8} \mathrm{Pc}\right] . \mathrm{m} / z$ (MALDI-TOF): calcd. for $\mathrm{C}_{152} \mathrm{H}_{129} \mathrm{Br}_{8} \mathrm{~N}_{16} \mathrm{Nd}_{2} \mathrm{O}_{8}$ 3235.5 [M+H], found 3236.3. UV-Vis $\left(\mathrm{CHCl}_{3}\right) \lambda$ (rel. int.) nm: 296 (0.267), 373 (0.392), 420 (1.000), $492(0.088), 605(0.054) .{ }^{1} \mathrm{H}$ NMR $\left(\mathrm{CDCl}_{3}\right) \delta_{\mathrm{H}} \mathrm{ppm}: 8.17(\mathrm{~d}, 8 \mathrm{H}$, $\left.{ }^{3} J=7.6 \mathrm{~Hz}, \mathrm{H}_{\mathrm{oo}}\right), 7.65\left(\mathrm{~s}, 16 \mathrm{H}, \mathrm{H}_{\mathrm{Por}}\right), 7.49\left(\mathrm{~d}, 8 \mathrm{H},{ }^{3} J=7.2 \mathrm{~Hz}, \mathrm{H}_{\mathrm{mo}}\right)$, $6.26\left(\mathrm{~s}, 8 \mathrm{H}, \mathrm{H}_{\mathrm{mi}}\right), 3.97\left(\mathrm{~s}, 8 \mathrm{H}, \mathrm{H}_{\mathrm{oo}}\right), 3.71\left(\mathrm{~s}, 8 \mathrm{H}, \mathrm{H}_{\mathrm{pc}}\right), 2.58(\mathrm{t}, 16 \mathrm{H}$, $\left.{ }^{3} J=5.9 \mathrm{~Hz}, \mathrm{H}^{1}\right), 1.03\left(\mathrm{~m}, 16 \mathrm{H}, \mathrm{H}^{2}\right), 0.90\left(\mathrm{~m}, 16 \mathrm{H}, \mathrm{H}^{3}\right), 0.57(\mathrm{t}, 16 \mathrm{H}$, $\left.{ }^{3} J=7.1 \mathrm{~Hz}, \mathrm{H}^{4}\right)$.

$\mathrm{Nd}_{2}\left[\mathrm{Br}_{4} \mathrm{TPP}\right]_{2}\left[(\mathrm{MeO})_{8} \mathrm{Pc}\right] . \mathrm{m} / \mathrm{z}$ (MALDI-TOF): calcd. for $\mathrm{C}_{128} \mathrm{H}_{81} \mathrm{Br}_{8} \mathrm{~N}_{16} \mathrm{Nd}_{2} \mathrm{O}_{8} 2898.8[\mathrm{M}+\mathrm{H}]$, found 2899.4. UV-Vis $\left(\mathrm{CHCl}_{3}\right)$ $\lambda_{\text {max }}$ (rel. int.) nm: 299 (0.254), 374 (0.498), 420 (1.000), 498 (0.113), 605 (0.072). ${ }^{1} \mathrm{H}$ NMR $\left(\mathrm{CDCl}_{3}\right) \delta_{\mathrm{H}} \mathrm{ppm}: 8.10\left(\mathrm{~d}, 8 \mathrm{H},{ }^{3} J=7.6 \mathrm{~Hz}\right.$, $\left.\mathrm{H}_{\mathrm{oo}}\right), 7.84\left(\mathrm{~s}, 16 \mathrm{H}, \mathrm{H}_{\mathrm{por}}\right), 7.49\left(\mathrm{~d}, 8 \mathrm{H},{ }^{3} \mathrm{~J}=6.6 \mathrm{~Hz}, \mathrm{H}_{\mathrm{mo}}\right), 6.32(\mathrm{~d}, 8 \mathrm{H}$, $\left.{ }^{3} J=6.6 \mathrm{~Hz}, \mathrm{H}_{\mathrm{mi}}\right), 3.88\left(\mathrm{~s}, 16 \mathrm{H}, \mathrm{H}_{\mathrm{Pc}_{\mathrm{c}}}+\mathrm{H}_{\mathrm{oi}}\right), 2.69\left(\mathrm{~s}, 8 \mathrm{H}, \mathrm{H}_{\mathrm{OMe}}\right)$.

$\mathrm{Nd}\left[\mathrm{Br}_{4}{ }_{\mathrm{mPP}}\right][\mathrm{Pc}] . \quad \mathrm{m} / \mathrm{z}$ (MALDI-TOF): calcd. for $\mathrm{C}_{76} \mathrm{H}_{41} \mathrm{Br}_{4} \mathrm{~N}_{12} \mathrm{Nd} 1586.1[\mathrm{M}+\mathrm{H}]$, found 1586.7. UV-Vis $\left(\mathrm{CHCl}_{3}\right) \lambda_{\text {max }}$ (rel. int.) nm: 283 (0.261), 336 (0.546), 418 (1.000), 484 (0.358), 599 (0.162), 789 (0.111).

$\mathrm{Nd}_{2}[\mathrm{DPP}]_{2}\left[(15 \mathrm{C5})_{4} \mathrm{Pc}\right] . \quad \mathrm{m} / \mathrm{z}$ (MALDI-TOF): calcd. for $\mathrm{C}_{128} \mathrm{H}_{113} \mathrm{~N}_{16} \mathrm{Nd}_{2} \mathrm{O}_{20} 2483.8$, found 2484.2. UV-Vis $\left(\mathrm{CHCl}_{3}\right) \lambda_{\text {max }}$ (rel. int.) nm: 293 (0.189), 373 (0.780), 411 (1.000), 484 (0.149), 599 (0.119). ${ }^{1} \mathrm{H}$ NMR $\left(\mathrm{CDCl}_{3}\right) \delta_{\mathrm{H}} \mathrm{ppm}: 9.04\left(\mathrm{~s}, 8 \mathrm{H}, \mathrm{H}_{\mathrm{Por}}\right), 8.81(\mathrm{~d}, 8 \mathrm{H}$, $\left.{ }^{3} J=7.1 \mathrm{~Hz}, \mathrm{H}_{\mathrm{oo}}\right), 7.66\left(\mathrm{t}, 8 \mathrm{H},{ }^{3} J=7.0 \mathrm{~Hz}, \mathrm{H}_{\mathrm{mo}}\right), 7.31\left(\mathrm{t}, 8 \mathrm{H},{ }^{3} J=7.2 \mathrm{~Hz}\right.$, $\left.\mathrm{H}_{\mathrm{p}}\right), 7.07\left(\mathrm{~s}, 4 \mathrm{H}, \mathrm{H}_{\mathrm{ms}}\right), 6.76\left(\mathrm{~s}, 8 \mathrm{H}, \mathrm{H}_{\mathrm{mi}}\right), 5.18\left(\mathrm{~s}, 8 \mathrm{H}, \mathrm{H}_{\mathrm{oi}}\right), 4.12(\mathrm{~s}$, $\left.8 \mathrm{H}, \mathrm{H}_{\mathrm{pc}}\right), 3.52\left(\mathrm{~m}, 16 \mathrm{H}, \mathrm{H}^{4}\right), 3.49\left(\mathrm{~m}, 16 \mathrm{H}, \mathrm{H}^{3}\right), 3.38\left(\mathrm{~m}, 16 \mathrm{H}, \mathrm{H}^{2}\right)$, $3.15\left(\mathrm{~m}, 16 \mathrm{H}, \mathrm{H}^{3}\right)$.

$\mathrm{Nd}_{2}[\mathrm{DPP}]\left[(15 \mathrm{C5})_{4} \mathrm{Pc}\right]_{2} . \mathrm{m} / \mathrm{z}$ (MALDI-TOF): calcd. for $\mathrm{C}_{160} \mathrm{H}_{165} \mathrm{~N}_{20} \mathrm{Nd}_{2} \mathrm{O}_{40} 3296.6[\mathrm{M}+\mathrm{H}]$, found 3297.1. UV-Vis $\left(\mathrm{CHCl}_{3}\right)$ $\lambda_{\text {max }}$ (rel. int.) nm: 293 (0.754), 368 (1.000), 409 (0.685), 616 
(0.363), 709 (0.242). ${ }^{1} \mathrm{H}$ NMR $\left(\mathrm{CDCl}_{3}\right) \delta_{\mathrm{H}} \mathrm{ppm}: 9.98$ (s, 8H, $\left.\mathrm{H}_{\text {por }}\right)$, $9.37\left(\mathrm{~s}, 8 \mathrm{H}, \mathrm{H}_{\mathrm{oo}}\right), 8.17\left(\mathrm{~s}, 8 \mathrm{H}, \mathrm{H}_{\mathrm{Por}}\right), 7.92\left(\mathrm{t}, 8 \mathrm{H},{ }^{3} \mathrm{~J}=6.5 \mathrm{~Hz}, \mathrm{H}_{\mathrm{mo}}\right)$, $7.36\left(\mathrm{t}, 8 \mathrm{H},{ }^{3} \mathrm{~J}=6.3 \mathrm{~Hz}, \mathrm{H}_{\mathrm{p}}\right), 6.98\left(\mathrm{~s}, 12 \mathrm{H}, \mathrm{H}_{\mathrm{mi}}+\mathrm{H}_{\mathrm{ms}}\right), 5.57\left(\mathrm{~s}, 8 \mathrm{H}, \mathrm{H}_{\mathrm{oi}}\right)$, $5.44\left(\mathrm{~s}, 8 \mathrm{H}, \mathrm{H}_{\mathrm{Pc}}\right), 4.44-2.70\left(\mathrm{~m}, 64 \mathrm{H}, \mathrm{H}^{(15 \mathrm{CS})}\right)$.

$\mathrm{La}\left[(\mathrm{BuO})_{8} \mathrm{Pc}\right]_{2} \cdot \mathrm{m} / \mathrm{z}$ (MALDI-TOF): calcd. for $\mathrm{C}_{128} \mathrm{H}_{160} \mathrm{La}-$ $\mathrm{N}_{16} \mathrm{O}_{16} 2316.1[\mathrm{M}]$, found 2315.9.

$\mathrm{La}_{2}[\mathrm{TPP}]_{2}\left[(\mathrm{BuO})_{8} \mathrm{Pc}\right] . \quad \mathrm{m} / \mathrm{z} \quad$ (MALDI-TOF): calcd. for $\mathrm{C}_{152} \mathrm{H}_{136} \mathrm{La}_{2} \mathrm{~N}_{16} \mathrm{O}_{8} 2590.9$ [M], found 2591.4. UV-Vis $\left(\mathrm{CHCl}_{3}\right) \lambda_{\text {max }}$ (lge) nm: 294 (4.02), 370 (4.36), 418 (4.65), 484 (3.66), 555 (3.4), 604 (3.45), 859 (3.24). ${ }^{1} \mathrm{H}$ NMR $\left(\mathrm{CDCl}_{3}\right) \delta_{\mathrm{H}} \mathrm{ppm}: 10.01(\mathrm{~d}, 8 \mathrm{H}$, $\left.{ }^{3} J=6.9 \mathrm{~Hz}, \mathrm{H}_{\mathrm{oi}}\right), 8.76\left(\mathrm{~s}, 8 \mathrm{H}, \mathrm{H}_{\mathrm{Pc}}\right), 8.29\left(\mathrm{t}, 8 \mathrm{H},{ }^{3} \mathrm{~J}=7.6 \mathrm{~Hz}, \mathrm{H}_{\mathrm{mi}}\right), 7.76$ $\left(\mathrm{t}, 8 \mathrm{H},{ }^{3} \mathrm{~J}=8.2 \mathrm{~Hz}, \mathrm{H}\right), 7.37\left(\mathrm{~s}, 16 \mathrm{H}, \mathrm{H}_{\mathrm{por}}\right), 7.27\left(\mathrm{t}, 8 \mathrm{H},{ }^{3} \mathrm{~J}=7.4 \mathrm{~Hz}\right.$, $\left.\mathrm{H}_{\mathrm{mo}}\right), 6.80\left(\mathrm{~d}, 8 \mathrm{H},{ }^{3} \mathrm{~J}=6.9, \mathrm{H}_{\mathrm{oo}}\right), 4.69\left(2 \mathrm{t}, 2 \times 8 \mathrm{H},{ }^{3} \mathrm{~J}=6.6 \mathrm{~Hz}, \mathrm{CH}_{2} \mathrm{O}\right)$, 2.34 (quin, $16 \mathrm{H},{ }^{3} \mathrm{~J}=7.2 \mathrm{~Hz}, \mathrm{CH}_{2}$ ), 1.99 (sext, $16 \mathrm{H},{ }^{3} \mathrm{~J}=7.5 \mathrm{~Hz}, \mathrm{CH}_{2}$ ), $1.37\left(\mathrm{t}, 24 \mathrm{H},{ }^{3} \mathrm{~J}=7.4 \mathrm{~Hz}, \mathrm{CH}_{3}\right)$.

$\mathrm{La}_{2}[\mathrm{TPP}]_{2}\left[(15 \mathrm{C} 5)_{8} \mathrm{Pc}\right] . \mathrm{m} / \mathrm{z}$ (MALDI-TOF): calcd. for $\mathrm{C}_{152} \mathrm{H}_{128} \mathrm{La}_{2} \mathrm{~N}_{16} \mathrm{O}_{20} 2775.8$ [M], found 2775.8. UV-Vis $\left(\mathrm{CHCl}_{3}\right) \lambda_{\max }$ (lge) nm: 293 (3.78), 370 (3.78), 420 (4.41), 479 (3.48), 554 (3.20), 605 (3.26), 864 (3.06). ' $\mathrm{H}$ NMR $\left(\mathrm{CDCl}_{3}\right) \delta_{\mathrm{H}} \mathrm{ppm}: 10.08(\mathrm{~d}, 8 \mathrm{H}$, $\left.{ }^{3} \mathrm{~J}=7.2 \mathrm{~Hz}, \mathrm{H}_{\mathrm{oi}}\right), 8.69\left(\mathrm{~s}, 8 \mathrm{H}, \mathrm{H}_{\mathrm{Pc}}\right), 8.31\left(\mathrm{t}, 8 \mathrm{H},{ }^{3} \mathrm{~J}=7.6 \mathrm{~Hz}, \mathrm{H}_{\mathrm{mi}}\right), 7.75$ $\left(\mathrm{t}, 8 \mathrm{H},{ }^{3} \mathrm{~J}=8.2 \mathrm{~Hz}, \mathrm{H}_{\mathrm{p}}\right), 7.36\left(\mathrm{~s}, 16 \mathrm{H}, \mathrm{H}_{\mathrm{por}}\right), 7.27\left(\mathrm{t}, 8 \mathrm{H},{ }^{3} J=7.3 \mathrm{~Hz}\right.$, $\left.\mathrm{H}_{\mathrm{mo}}\right), 6.81\left(\mathrm{~d}, 8 \mathrm{H},{ }^{3} J=7.0 \mathrm{~Hz}, \mathrm{H}_{\mathrm{oo}}\right), 4.75-4.83\left(\mathrm{~m}, 16 \mathrm{H}, \mathrm{CH}_{2}\right), 4.39-$ $4.33\left(\mathrm{~m}, 16 \mathrm{H}, \mathrm{CH}_{2}\right), 4.04-3.99\left(\mathrm{~m}, 32 \mathrm{H}, \mathrm{CH}_{2}\right)$.

$\mathrm{La}_{2}[\mathrm{TBP}]_{2}\left[(\mathrm{BuO})_{8} \mathrm{Pc}\right] . \quad \mathrm{m} / \mathrm{z}$ (MALDI-TOF): calcd. for $\mathrm{C}_{184} \mathrm{H}_{200} \mathrm{La}_{2} \mathrm{~N}_{16} \mathrm{O}_{8} 3039.3$ [M], found 3039.9. UV-Vis $\left(\mathrm{CHCl}_{3}\right) \lambda_{\text {max }}$ (lge) nm: 294 (3.73), 372 (4.07), 420 (4.29), 485 (3.39), 557 (3.14), 605 (3.16), 851 (2.29). ${ }^{1} \mathrm{H}$ NMR $\left(\mathrm{CDCl}_{3}\right) \delta_{\mathrm{H}} \mathrm{ppm}: 9.42(\mathrm{~d}, 8 \mathrm{H}$, $\left.{ }^{3} J=7.1 \mathrm{~Hz}, \mathrm{H}_{\mathrm{oi}}\right), 8.79\left(\mathrm{~s}, 8 \mathrm{H}, \mathrm{H}_{\mathrm{Pc}}\right), 8.14\left(\mathrm{~d}, 8 \mathrm{H},{ }^{3} J=6.8 \mathrm{~Hz}, \mathrm{H}_{\mathrm{mi}}\right), 7.39$ $\left(\mathrm{s}, 16 \mathrm{H}, \mathrm{H}_{\mathrm{Por}}\right), 7.20\left(\mathrm{~d}, 8 \mathrm{H},{ }^{3} \mathrm{~J}=6.8 \mathrm{~Hz}, \mathrm{H}_{\mathrm{mo}}\right), 6.61\left(\mathrm{~d}, 8 \mathrm{H},{ }^{3} \mathrm{~J}=7.3 \mathrm{~Hz}\right.$, $\left.\mathrm{H}_{\mathrm{oo}}\right), 4.79\left(2 \mathrm{t}, 2 \times 8 \mathrm{H},{ }^{3} \mathrm{~J}=5.9 \mathrm{~Hz}, \mathrm{CH}_{2} \mathrm{O}\right), 2.37-2.31\left(\mathrm{~m}, 16 \mathrm{H}, \mathrm{CH}_{2}\right)$, $2.04\left(\mathrm{sext}, 16 \mathrm{H},{ }^{3} \mathrm{~J}=4.7, \mathrm{CH}_{2}\right), 1.64\left(\mathrm{~s}, 72 \mathrm{H}, \mathrm{H}_{\mathrm{tBu}}\right), 1.35(\mathrm{t}, 24 \mathrm{H}$, $\left.{ }^{3} \mathrm{~J}=7.3 \mathrm{~Hz}, \mathrm{CH}_{3}\right)$.

\section{Results and Discussion}

Following our previously developed approach for the preparation of heteroleptic triple-decker lanthanide (porphyrinato)(phthalocyaninates) ${ }^{[19,21-26]}$ we have involved a series of free-base porphyrins and phthalonitriles into interaction with lanthanide acetylacetonates. Within the studied series, the steric and electronic properties of the ligands were varied (Figure 1). In turn, the application of 5,15-diphenylporphyrin in the synthesis allowed testing of the applicability of the thermally labile meso-unsubstituted porphyrins in the discussed general synthetic route.

In general, the discussed synthetic approach to the heteroleptic lanthanide (porphyrinato)(phthalocyaninates) consists
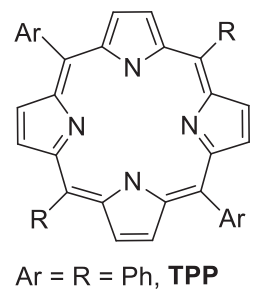

$\mathrm{Ar}=\mathrm{R}=4-\mathrm{MeC}_{6} \mathrm{H}_{4}, \mathrm{TTP}$

$\mathrm{Ar}=\mathrm{R}=4-{ }^{\mathrm{t}} \mathrm{BuC}_{6} \mathrm{H}_{4}, \mathrm{TBP}$

$\mathrm{Ar}=\mathrm{R}=$ Mes, TMP

$\mathrm{Ar}=\mathrm{R}=4-\mathrm{BrC}_{6} \mathrm{H}_{4}, \mathrm{Br}_{4} \mathrm{TPP}$

$\mathrm{Ar}=\mathrm{Ph}, \mathrm{R}=\mathrm{H}, \mathrm{DPP}$

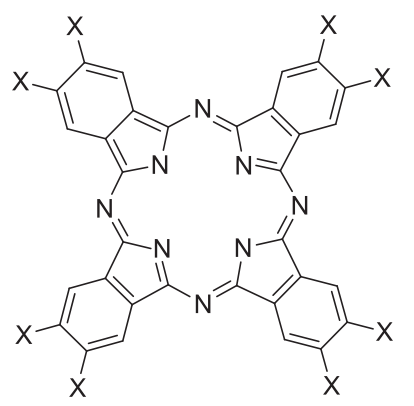

$X=$ fused 15 -crown-5, $(15 \mathrm{C} 5)_{4} P c$

$\mathrm{X}=\mathrm{OBu},(\mathrm{BuO})_{8} \mathrm{Pc}$

$\mathrm{X}=\mathrm{OMe},(\mathrm{MeO})_{8} \mathrm{Pc}$

$\mathrm{X}=\mathrm{H}, \mathrm{Pc}$

Figure 1. The designation of ligands used in present work.

in prolonged reflux of the free-base porphyrin, phthalonitrile and lanthanide acetylacetonate in 1-hexanol in the presence of DBU for $24 \mathrm{~h}$. The significance of the preservation of the inert atmosphere in the synthesis has been previously mentioned. ${ }^{[21,22]}$ Moreover, we have revealed that the reaction is virtually suppressed when performed under argon atmosphere without flow of inert gas that is required for the elimination of the formed acetylacetone. The comparison of structure and yields of the obtained complexes allowed evaluation of the influence of ligands onto the reaction path (Table 1).

Table 1. Synthesis of the triple-decker heteroleptic lanthanide complexes.

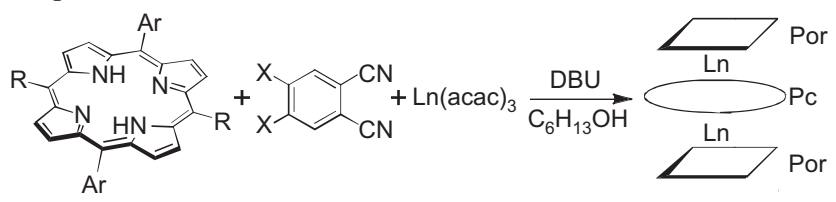

\begin{tabular}{cccc}
\hline Entry & Por & Pc & TD yield (Ln) \\
\hline 1 & $\mathrm{Br}_{4} \mathrm{TPP}$ & $(15 \mathrm{C} 5)_{4} \mathrm{Pc}$ & $63 \%(\mathrm{La})_{,}^{[23]} 55 \%(\mathrm{Nd})^{[23]}$ \\
2 & $\mathrm{Br}_{4} \mathrm{TPP}$ & $(\mathrm{BuO})_{8} \mathrm{Pc}$ & $56 \%(\mathrm{Nd})$ \\
3 & $\mathrm{Br}_{4} \mathrm{TPP}$ & $(\mathrm{MeO})_{8} \mathrm{Pc}$ & $6 \%(\mathrm{Nd})$ \\
4 & $\mathrm{Br}_{4} \mathrm{TPP}$ & $\mathrm{Pc}$ & $\mathrm{N} / \mathrm{d}(\mathrm{Nd})^{\mathrm{a}}$ \\
5 & $\mathrm{TPP}$ & $(15 \mathrm{C} 5)_{4} \mathrm{Pc}$ & $67 \%(\mathrm{La})$ \\
6 & $\mathrm{TPP}$ & $(\mathrm{BuO})_{8} \mathrm{Pc}$ & $44 \%(\mathrm{La})$ \\
7 & $\mathrm{TTP}$ & $(\mathrm{BuO})_{8} \mathrm{Pc}$ & $\mathrm{N} / \mathrm{d}(\mathrm{La})^{\mathrm{b}}$ \\
8 & $\mathrm{TBP}$ & $(\mathrm{BuO})_{8} \mathrm{Pc}$ & $69 \%(\mathrm{La})$ \\
9 & $\mathrm{TMP}$ & $(\mathrm{BuO})_{8} \mathrm{Pc}$ & $\mathrm{N} / \mathrm{d}(\mathrm{La})^{\mathrm{c}}$ \\
10 & $\mathrm{DPP}$ & $(15 \mathrm{C} 5)_{4} \mathrm{Pc}$ & $\mathrm{Trace}(\mathrm{Nd})$ \\
\hline
\end{tabular}

${ }^{\mathrm{a}}$ Heteroleptic neodymium double-decker complex is formed in $44 \%$ yield. ${ }^{b}$ The starting porphyrin was insoluble in reaction medium and was recovered. 'Homoleptic lanthanum diphthalocyaninate is formed in $70 \%$ yield.

According to the previously published data, ${ }^{[23]}$ the lanthanum(III) and neodymium(III) triple-decked heteroleptic complexes with tetra(4-bromophenyl)porphyrinato and tetra(15-crown-5)phthalocyaninato ligands were prepared with $63 \%$ and $55 \%$ yields, respectively (entry 1 ). The change of the central ligand to octabutoxyphthalocyanine reveals no influence onto the yield of the triple-decker complex (entry 2). In contrast, in the case of application of dimethoxyphthalonitrile in the synthesis (entry 3 ), the corresponding triple-decker complex was isolated with only $6 \%$ yield, while octamethoxyphthalocyanine ${ }^{[30]}$ was found to be the main product of the reaction. Presumably, low solubility of the free-base $(\mathrm{MeO})_{8} \mathrm{PcH}_{2}$ and its precipitation from the reaction mixture facilitated its formation resulting in efficient removal of the phthalonitrile from the reaction medium. Thus, the presence of electron-donating groups in the phthalocyanine macrocycle was found to be crucial for the formation of the triple-decker [Por] $\operatorname{Ln}[\mathrm{Pc}] \mathrm{Ln}[\mathrm{Por}]$ complexes and was testified by the application of unsubstituted phthalonitrile in the synthesis (entry 4). In this case the specific formation of the corresponding double- 
decker complex $\left[\mathrm{Br}_{4} \mathrm{TPP}\right] \mathrm{Nd}[\mathrm{Pc}]$ was observed. Even trace amounts of desired triple-decker complex were not detected in the reaction mixture. In this case, it can be concluded that excess of electronic density on the phthalocyanine deck is required for the formation of a triple-decker compound. Nevertheless, the related triple-decker complexes bearing an unsubstituted phthalocyanine deck were reported, ${ }^{[31-33]}$ that testifies their stability. In contrast, only a step-wise "raise-by-one-story" approach was successfully applied for their synthesis. The fact that the published synthesis of the triple-decker complexes was successfully performed with 1,2,4-trichlorobenzene as solvent proves their stability under reflux in high-boiling solvent. In our case we presume that higher polarity of 1-hexanol could result in complete dissociation of the compound, even if it is formed under reaction conditions.

Changing tetra(4-bromophenyl)porphyrin in the synthesis to tetraphenylporphyrin does not reveal significant influence onto the reaction path (entries 5,6). On the other hand, the sufficient solubility of the porphyrin in the reaction medium is required for the successful interaction as testified by the application tetra(4-tolyl)porphyrin (entry 7). In this case, the low solubility of the starting porphyrin resulted in complete suppression of the formation of heteroleptic complexes of any type. Considering this observed peculiarity, we involved tetra(4-tert-butylphenyl)porphyrin bearing the bulky fragments for enhancement of solubility into the interaction (entry 8). In contrast to the previous entry, the expected triple-decker complex was isolated with $67 \%$ yield. Further increase of the bulkiness of the porphyrin meso-substituents was performed by the introduction of mesityl groups (entry 9). This modification has switched the selectivity of the reaction to the formation of the homoleptic lanthanum diphthalocyaninate $\mathrm{La}\left[(\mathrm{BuO})_{8} \mathrm{Pc}\right]_{2}$ as a redox mixture.

The behavior of 5,15-diphenylporphyrin in the reaction completely differs from that of tetraarylporphyrins (entry 10). The thermal lability of the porphyrin bearing unsubstituted meso-position results in its considerable decomposition under reaction conditions. In turn, the porphyrin/phthalonitrile ratio in the reaction significantly changes, providing the mixture of heteroleptic complexes [DPP] $\operatorname{Ln}\left[(15 \mathrm{C} 5)_{4} \mathrm{Pc}\right] \mathrm{Ln}[\mathrm{DPP}]$, $[\mathrm{DPP}] \operatorname{Ln}\left[(15 \mathrm{C} 5)_{4} \mathrm{Pc}\right] \operatorname{Ln}\left[(15 \mathrm{C} 5)_{4} \mathrm{Pc}\right]$ and $[\mathrm{DPP}] \operatorname{Ln}\left[(15 \mathrm{C} 5)_{4} \mathrm{Pc}\right]$ in $<5 \%$ yield each. This result is in conformity with the published targeted synthesis of heteroleptic double-decker complexes involving diarylporphyrins, which were synthesized in 5-20\% yields. $^{[3]}$

All the synthesized triple-decker lanthanide complexes were isolated by means of column chromatography and sufficiently characterized with ${ }^{1} \mathrm{H}$ NMR, UV-Vis and MALDITOF MS. Among these methods UV-Vis remains significantly informative tool for elucidation of the deviations in the electronic structure of the metal complexes with tetrapyrrolic ligands. Table 2 summarizes the absorption spectral data of the synthesized complexes. In general, the comparison of the positions of the main bands in the spectra does not reveal any structural peculiarities within the synthesized series. The only exception is observed for the complex, containing diphenylporphyrinato ligand (Table 2 , entry 8 ). In this case, two bands corresponding the predominantly porphyrinic transitions reveal the slight hypsochromic shift ca. 7-9 nm (marked in bold in the table).
Table 2. UV-Vis spectral data of the prepared triple-decker complexes [Por] $\mathrm{Ln}[\mathrm{Pc}] \operatorname{Ln}[\mathrm{Por}]$ type $\left(\mathrm{CHCl}_{3}\right)$.

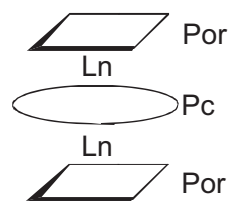

\begin{tabular}{ccccc}
\hline Entry & Por & Pc & $\mathrm{Ln}$ & $\lambda_{\max }, \mathrm{nm}$ \\
\hline 1 & $\mathrm{Br}_{4} \mathrm{TPP}$ & $(15 \mathrm{C} 5)_{4} \mathrm{Pc}$ & $\mathrm{La}$ & $293,373,421,482,606^{[23]}$ \\
2 & $\mathrm{Br}_{4} \mathrm{TPP}$ & $(15 \mathrm{C} 5)_{4} \mathrm{Pc}$ & $\mathrm{Nd}$ & $297,374,421,487,607^{[23]}$ \\
3 & $\mathrm{Br}_{4} \mathrm{TPP}$ & $(\mathrm{BuO})_{8} \mathrm{Pc}$ & $\mathrm{Nd}$ & $296,373,420,492,605$ \\
4 & $\mathrm{Br}_{4} \mathrm{TPP}$ & $(\mathrm{MeO})_{8} \mathrm{Pc}$ & $\mathrm{Nd}$ & $299,374,420,498,605$ \\
5 & $\mathrm{TPP}$ & $(15 \mathrm{C} 5)_{4} \mathrm{Pc}$ & $\mathrm{La}$ & $293,370,420,479,605$ \\
6 & $\mathrm{TPP}$ & $(\mathrm{BuO})_{8} \mathrm{Pc}$ & $\mathrm{La}$ & $294,370,418,484,604$ \\
7 & $\mathrm{TBP}$ & $(\mathrm{BuO})_{8} \mathrm{Pc}$ & $\mathrm{La}$ & $294,372,420,485,605$ \\
8 & $\mathrm{DPP}$ & $(15 \mathrm{C} 5)_{4} \mathrm{Pc}$ & $\mathrm{Nd}$ & $293,373, \mathbf{4 1 1}, 484, \mathbf{5 9 9}$ \\
\hline
\end{tabular}

NMR spectroscopy provides additional structural information on the complexes, since this method is also highly sensitive to the structure of heteroleptic lanthanide complexes with tetrapyrrolic ligands..$^{[34-39]}$ In the presence of paramagnetic metal center the lanthanide-induced shift (LIS) of resonances results in significant difference in chemical shifts between the related complexes of $\mathrm{La}(\mathrm{III})$ and Nd(III). The specific orientation and high barrier of inversion of the porphyrin meso-aryl groups in the heteroleptic complexes of discussed type ${ }^{[40,41]}$ lead to decrease of symmetry of the mentioned fragment. In this case, all the protons in the aryl groups become magnetically non-equivalent with respect to inner- or outer-orientation. ${ }^{[35]}$ Figure 2 shows the ${ }^{1} \mathrm{H}$ NMR spectrum of [TPP $] \mathrm{La}\left[(\mathrm{BuO})_{8} \mathrm{Pc}\right] \mathrm{La}[\mathrm{TPP}]$ in $\mathrm{CDCl}_{3}$. Five resonances, namely 2 doublets and 3 triplets, can be clearly observed in the region of aromatic proton resonances, corresponding to protons of meso-phenyl groups. According to our previously developed structural model of this type of complexes, the most upfield shifted doublet among them corresponds to the outer-oriented ortho-proton of the phenyl group. Similarly, the downfield-shifted doublet is unambiguously assigned to the inner-oriented ortho-proton. In this respect 3 remaining triplets could be assigned to metaand para-protons of the aromatic ring, while two narrow singlets with 2:1 ratio obviously correspond to equivalent porphyrin and phthalocyanine aromatic protons. The region of aliphatic proton resonances of the spectrum shows 4 multiplets, corresponding to the fragments of butoxy-group. It should be mentioned that the resonance corresponding to $\mathrm{CH}_{2} \mathrm{O}$ fragment is composed of two overlapping triplets with ${ }^{3} J=6.6 \mathrm{~Hz}$ with $2.7 \mathrm{~Hz}$ shift ( $c a .0 .005 \mathrm{ppm}$ ). As an assumption we attribute this shape of the signal to two different orientations of this $\mathrm{CH}_{2}$-group in the molecule with hindered exchange between them.

${ }^{1} \mathrm{H}-{ }^{1} \mathrm{H}-\mathrm{COSY}$ spectrum of the complex allows confirmation of the mentioned assignment of the resonances in the spectrum of $[\mathrm{TPP}] \mathrm{La}\left[(\mathrm{BuO})_{8} \mathrm{Pc}\right] \mathrm{La}[\mathrm{TPP}]$ (Figure 3 ). The COSY spectrum clearly reveals the sequential correlations through the ${ }^{3} J$-couplings between $\mathrm{H}_{\mathrm{oi}}-\mathrm{H}_{\mathrm{mi}}-\mathrm{H}_{\mathrm{p}}-\mathrm{H}_{\mathrm{mo}}-\mathrm{H}_{\mathrm{oo}}$. 


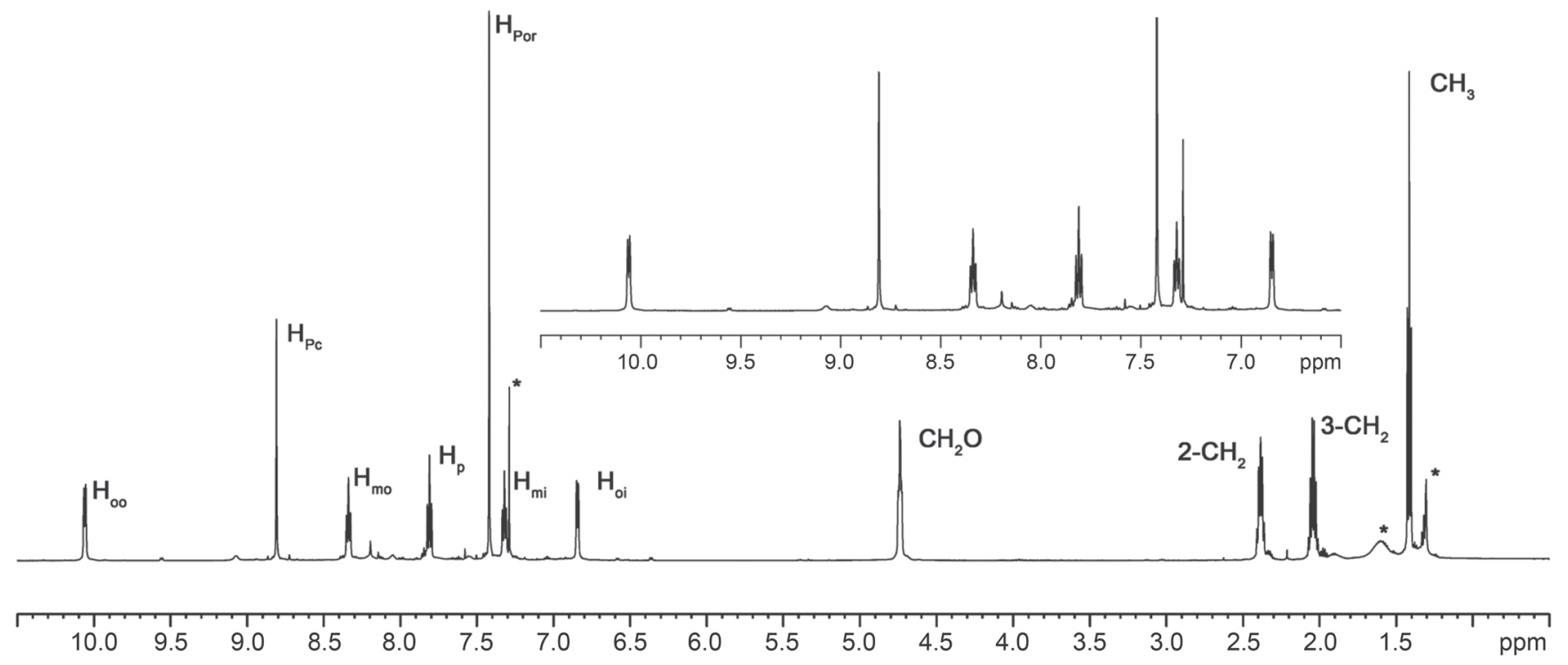

Figure 2. ${ }^{1} \mathrm{H}$ NMR spectrum of $[\mathrm{TPP}] \mathrm{La}\left[(\mathrm{BuO})_{8} \mathrm{Pc}\right] \mathrm{La}[\mathrm{TPP}]$ in $\mathrm{CDCl}_{3}$. The residual pick and impurities of the solvent are marked with asterisks.

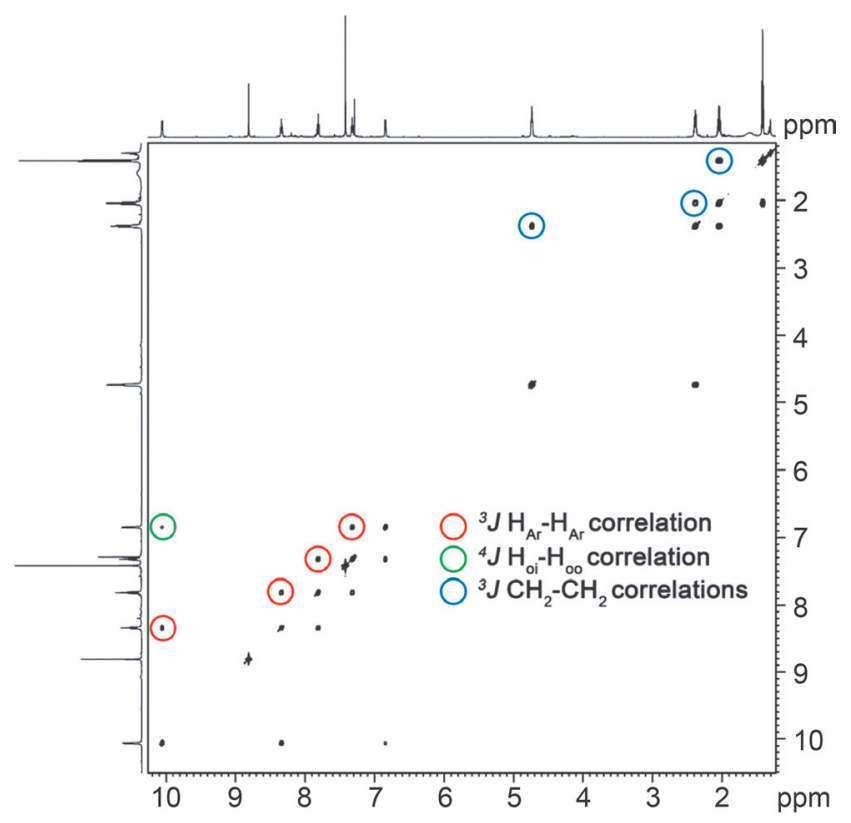

Figure 3. ${ }^{1} \mathrm{H}-{ }^{1} \mathrm{H}-\mathrm{COSY}$ spectrum of $[\mathrm{TPP}] \mathrm{La}\left[(\mathrm{BuO})_{8} \mathrm{Pc}\right] \mathrm{La}[\mathrm{TPP}]$ in $\mathrm{CDCl}_{3}$.
Moreover, a weak cross-peak corresponding to the ${ }^{4} J$-coupling between $\mathrm{H}_{\mathrm{oi}}$ and $\mathrm{H}_{\mathrm{oo}}$ could also be observed. In the case of butoxy-group resonances, all the expected correlations of the aliphatic chain are also observed. Thus, the complete assignment of the proton resonances in the spectrum is unambiguously verified and it is in conformity with the previously published assignments of the related complexes. ${ }^{[23]}$

The NMR data of the synthesized compounds of [Por] $\mathrm{Ln}[\mathrm{Pc}] \mathrm{Ln}[\mathrm{Por}]$ type are summarized in Table 3. The previously described related lanthanum(III) and neodymium(III) complexes ${ }^{[23]}$ are used as comparative references of chemical shifts. The combination of magnetic anisotropy of the aromatic rings and the influence of the paramagnetic origin of the lanthanide ion makes the chemical shifts of the protons in this type of molecules extremely sensitive even to minor structural deviations. It can be noted, that in the case of diamagnetic lanthanum(III) complexes the chemical shifts of the macrocyclic porphyrins and phthalocyanine protons remain virtually unchanged upon variation of the substituents of the ligands. Moreover, the positions of the meso-aryl protons resonances are dependent rather on the type of parasubstituent then the origin of the phthalocyanine deck.

Table 3. ${ }^{1} \mathrm{H}$ NMR data for the synthesized triple-decker complexes [Por] $\operatorname{Ln}[\mathrm{Pc}] \mathrm{Ln}[\mathrm{Por}]$ in $\mathrm{CDCl}_{3}$.

\begin{tabular}{ccccccccccc}
\hline Por & $\mathrm{Pc}$ & $\mathrm{Ln}$ & $\mathrm{H}_{\mathrm{oi}}$ & $\mathrm{H}_{\mathrm{mi}}$ & $\mathrm{H}_{\mathrm{p}}$ & $\mathrm{H}_{\mathrm{mo}}$ & $\mathrm{H}_{\mathrm{oo}}$ & $\mathrm{H}_{\mathrm{Pc}}$ & $\mathrm{H}_{\text {Por }}$ & Pc alkyl groups $^{\mathrm{a}}$ Ref. \\
\hline$B r_{4} T P P$ & $(15 C 5)_{4} P c$ & $\mathrm{La}$ & 9.43 & 8.40 & - & 7.44 & 6.61 & 8.59 & 7.42 & $4.84,4.47,4.13,4.09$ \\
$\mathrm{TPP}$ & $(15 \mathrm{C} 5)_{4} \mathrm{Pc}$ & $\mathrm{La}$ & 10.08 & 8.31 & 7.75 & 7.27 & 6.81 & 8.69 & 7.36 & $4.78,4.36,4.07,4.01$ \\
$\mathrm{TPP}$ & $(\mathrm{BuO})_{8} \mathrm{Pc}$ & $\mathrm{La}$ & 10.01 & 8.29 & 7.76 & 7.27 & 6.80 & 8.76 & 7.37 & $4.69,2.34,1.99,1.37$ \\
$\mathrm{TBP}^{\mathrm{b}}$ & $(\mathrm{BuO})_{8} \mathrm{Pc}$ & $\mathrm{La}$ & 9.42 & 8.14 & - & 7.20 & 6.61 & 8.79 & 7.39 & $2.35,2.04,1.64,1.35$ \\
$B r_{4} T P P$ & $(15 C 5)_{4} P c$ & $\mathrm{Nd}$ & 3.83 & 6.26 & - & 7.45 & 8.14 & 3.61 & 7.70 & $3.39,3.32,3.14,2.64$ \\
$\mathrm{Br}_{4} \mathrm{TPP}$ & $(\mathrm{BuO})_{8} \mathrm{Pc}$ & $\mathrm{Nd}$ & 3.97 & 6.26 & - & 7.49 & 8.17 & 3.71 & 7.65 & $2.58,1.03,0.90,0.57$ \\
$\mathrm{Br}_{4} \mathrm{TPP}$ & $(\mathrm{MeO})_{8} \mathrm{Pc}$ & $\mathrm{Nd}$ & 3.88 & 6.32 & - & 7.49 & 8.10 & 3.88 & 7.84 & 2.69 \\
$\mathrm{DPP}^{\mathrm{c}}$ & $(15 \mathrm{C} 5)_{4} \mathrm{Pc}$ & $\mathrm{Nd}$ & 5.18 & 6.76 & 7.31 & 7.66 & 8.81 & 4.12 & 9.04 & $3.52,3.49,3.38,3.15$ \\
\hline
\end{tabular}

a In the case of multiplets their centers are denoted. ${ }^{\mathrm{b}}$ The singlet of tert-butyl group is omitted. ${ }^{\mathrm{C}}$ The resonance of porphyrins meso-proton is omitted. 
In contrast, in the case of paramagnetic neodymium(III) complexes the slight variation in chemical shifts is observed within the series, since the LIS of the resonances is significantly dependent on the respective position of the lanthanide ion and the corresponding nuclei in the molecule. For instance, the resonances of the meso-substituents of $\mathrm{Br}_{4} \mathrm{TPP}$ ligand slightly differ upon variation of the phthalocyanine deck substituents, that could reasonably be assigned to minor structural deviations of these complexes. Nevertheless, the comparison of the chemical shifts within the series generally testifies the performed assignments and the structural relations of the obtained complexes.

\section{Conclusions}

We have investigated the scope and limitations of the previously developed one-step synthetic approach for the preparation of heteroleptic early lanthanide triple-decker (porphyrinato)(phthalocyaninates). The presence of electrondonating substituents is a key factor for the efficient formation of the triple-decker complexes of [Por]Ln[Pc]Ln[Por] type. Moreover, the application of porphyrin ligands containing unsubstituted meso-positions is limited because of their thermal lability. Introduction of bulky meso-aryl groups to the porphyrin ligand is also a limiting factor for the formation of the triple-decked complexes, presumably as a result of the intramolecular sterical repulsion between decks. The analysis of the UV-Vis and NMR spectra of the prepared complexes reveals the close structural relation between them despite the origin of the applied ligands.

Acknowledgements. The work was sponsored by the Council of the Russian President for support of young scientists (MK-6536.2016.3). The measurements were performed using equipment of CKP FMI IPCE RAS.

\section{References}

1. Horii Y., Katoh K., Yasuda N., Breedlove B.K., Yamashita M. Inorg. Chem. 2015, 54, 3297-3305. X., Kong X., Chen Y., Jiang J. ACS Appl. Mater. Interfaces 2015, 7, 2486-2493.

3. Zhu P., Zhang X., Wang H., Zhang Y., Bian Y., Jiang J. Inorg. Chem. 2012, 51, 5651-5659.

4. Lindsey J.S., Bocian D.F. Acc. Chem. Res. 2011, 44, 638-650.

5. Padmaja K., Youngblood W.J., Wei L., Bocian D.F., Lindsey J.S. Inorg. Chem. 2006, 45, 5479-5492.

6. Lysenko A.B., Malinovskii V.L., Padmaja K., Wei L., Diers J.R., Bocian D.F., Lindsey J.S. J. Porphyrins Phthalocyanines 2005, 9, 491-508.

7. Dreiser J. J. Phys.: Condens. Matter 2015, 27, 183-203.

8. Tang J., Zhang P. Lanthanide Single Molecule Magnets. Berlin, Heidelberg: Springer Berlin Heidelberg, 2015.

9. Wang H., Wang B.-W.W., Bian Y., Gao S., Jiang J. Coord. Chem. Rev. 2016, 306, 195-216.

10. Bertani F., Cristiani N., Mannini M., Pinalli R., Sessoli R., Dalcanale E. Eur. J. Org. Chem. 2015, 2015(32), 7036-7042.
11. Kan J., Wang H., Sun W., Cao W., Tao J., Jiang J. Inorg. Chem. 2013, 52, 8505-8510.

12. Li Z., Gao F., Xiao Z., Ao G., Wu X., Fang Y., Nie Z., Wei T.-H., Yang J., Wang Y., Zhang X., Zuo J., Song Y. Dyes Pigm. 2015, 119, 70-74.

13. Sheng N., Liu D., Gu B., He J., Cui Y. Dyes Pigm. 2015, 122, 346-350.

14. Pushkarev V.E., Tomilova L.G., Nemykin V.N. Coord. Chem. Rev. 2016, 319, 110-179.

15. Lu F.-L., Mao Y.-J., Wang W.-D., Xiao C. Dyes Pigm. 2013, 99 , 686-692.

16. Zhou Y., Zhang Y., Wang H., Jiang J., Bian Y., Muranaka A., Kobayashi N. Inorg. Chem. 2009, 48, 8925-8933.

17. Jiang J., Ng D.K.P. Acc. Chem. Res. 2009, 42, 79-88.

18. Lu J., Deng Y., Zhang X., Kobayashi N., Jiang J. Inorg. Chem. 2011, 50, 2562-2567.

19. Birin K.P., Gorbunova Y.G., Tsivadze A.Y. Dalton Trans. 2012 , 41,9672 .

20. Zhu P., Pan N., Li R., Dou J., Zhang Y., Cheng D.Y.Y., Wang D., Ng D.K.P., Jiang J. Chem. - A Eur. J. 2005, 11, 1425-1432.

21. Birin K.P., Gorbunova Y.G., Tsivadze A.Yu. J. Porphyrins Phthalocyanines 2009, 13, 283-290.

22. Birin K.P., Gorbunova Y.G., Tsivadze A.Y. Macroheterocycles 2010, 3, 210-217.

23. Birin K.P., Gorbunova Y.G., Tsivadze A.Y. Dalton Trans. 2011, 40, 11539.

24. Birin K.P., Kamarova K.A., Gorbunova Y.G., Tsivadze A.Y. J. Porphyrins Phthalocyanines 2013, 17, 1027-1034.

25. Birin K.P., Gorbunova Y.G., Tsivadze A.Y. Prot. Met. Phys. Chem. Surfaces 2011, 47, 417-423.

26. Birin K.P., Kamarova K.A., Gorbunova Y.G., Tsivadze A.Y. Prot. Met. Phys. Chem. Surfaces 2013, 49, 173-180.

27. Adler A.D., Longo F.R., Finarelli J.D., Goldmacher J., Assour J., Korsakoff L. J. Org. Chem. 1967, 32, 476-476.

28. Martynov A.G., Birin K.P., Gorbunova Y.G., Tsivadze A.Y. Macroheterocycles 2013, 6, 23-32.

29. Gorbunova Y.G., Komarova O.Y., Demin S.V., Meshkov S.V., Tsivadze A.Y. Russ. J. Coord. Chem. 1997, 23, 516-519.

30. Wörle D., Schnurpfeil G., Knothe G. Dyes Pigm. 1992, 18, 91-102.

31. Lu J., Zhang D., Wang H., Jiang J., Zhang X. Inorg. Chem. Commun. 2010, 13, 1144-1147.

32. Sun X., Li R., Wang D., Dou J., Zhu P., Lu F., Ma C., Choi C.F., Cheng D.Y.Y., Ng D.K.P., Kobayashi N., Jiang J. Eur. J. Inorg. Chem. 2004, 3806-3813.

33. Sun X. Synth. Met. 2008, 158, 917-921.

34. Damjanovic M., Morita T., Katoh K., Yamashita M., Enders M. Chem. - A Eur. J. 2015, 21, 14421-14432.

35. Birin K.P., Gorbunova Y.G., Tsivadze A.Y. Magn. Reson. Chem. 2010, 48, 505-515.

36. Damjanovic M., Katoh K., Yamashita M., Enders M. J. Am. Chem. Soc. 2013, 135, 14349-14358.

37. Geraldes C.F.G.C., Zhang S., Sherry A.D. Bioinorg. Chem Appl. 2003, 1, 1-23.

38. Polovkova M.A., Martynov A.G., Birin K.P., Nefedov S.E., Gorbunova Y.G., Tsivadze A.Y. Inorg. Chem. 2016, 55, 9258 9269.

39. Martynov A.G., Gorbunova Y.G., Tsivadze A.Y. Dalton Trans. 2011, 40, 7165-7171.

40. Birin K.P., Gorbunova Y.G., Tsivadze A.Y. Dalton Trans. 2011 40, 11474.

41. Birin K.P., Gorbunova Y.G., Tsivadze A.Y. J. Porphyrins Phthalocyanines 2011, 15, 667-673. 